\title{
Endogenous Nitrogen Excretion and Non-fecal Energy Losses in Carp and Rainbow Trout ${ }^{\dagger}$
}

\author{
Takeshi Watanabe*1 and Masahiro Ohta*2 \\ ${ }^{* 1}$ Laboratory of Fish Nutrition, Tokyo University of Fisheries, Konan, Minato, Tokyo 108, Japan \\ ${ }^{* 2}$ Aquaculture Research Center, Nippon Formula Feed Mfg. Co., Ltd., Oozima, Yaizu, Shizuoka 425, Japan
}

(Received July 14, 1994)

\begin{abstract}
This series of studies on nutritional energetics in carp and rainbow trout aims to provide basic data necessary for standardization of feed quality evaluation for fish in captivity. At the outset, endogenous nitrogen excretion (ENE) through the gills and in the urine was determined by feeding a non-protein diet which is essential for calculation of metabolizable energy.

The amounts of ENE in carp of $21-289 \mathrm{~g}$ were $5.6-9.3 \mathrm{mg} / 100 \mathrm{~g}$ body weight/day and decreased with increase of fish body weight and with decrease of water temperature. The rates of ENE were $10.0-15.7 \mathrm{mg} / 100 \mathrm{~g} \mathrm{BW} /$ day for carp weighing below $20 \mathrm{~g}$. The ENE rates in rainbow trout were proportional to water temperature, ranging from $6.6 \mathrm{mg}$ at $14^{\circ} \mathrm{C}$ to $12.4 \mathrm{mg}$ at $21^{\circ} \mathrm{C}(9.0 \mathrm{mg}$ on average $)$.

Secondly, to determine non-fecal energy losses carp or rainbow trout weighing more than $100 \mathrm{~g}$ were fed four kinds of experimental diets. There were no marked differences in the non-fecal losses among the fish fed the same diet once or three times daily at almost the same feeding levels. The proportion of energy lost through non-fecal wastes seems to be not so influenced by temperature.
\end{abstract}

Key words: endogenous nitrogen excretion, non-fecal energy loss, carp, rainbow trout, body weight, water temperature, feeding frequency

Of late in Japan, the total production of formulated feeds for aquaculture has been on the rise and is now about $350,000 \mathrm{t}$, thereby augmenting finfish production. However, precise methods for evaluating the nutritional quality of diets are not available for each fish species, except the official standard which specifies a lower limit of crude protein and crude fat and an upper limit of crude ash and crude fiber for carp, rainbow trout, eel, and Ayu diets. In contrast, the nutritional quality of diets and feedstuffs for mammals is evaluated by various indices such as total digestible nutrients (TDN), digestible energy (DE), metabolizable energy (ME), and net energy (NE). ${ }^{1-3)}$ Energy requirements for maintenance, growth, and production of milk, eggs, etc. have been investigated by many researchers and are used in practice. ${ }^{4}$ Successful fish culture depends upon the provision of diets containing an appropriate balance of nutrients and adequate energy to permit the most efficient growth of the fish. Measurement of dietary energy cost for fish production in captivity is of great importance for scientific aquaculture. Consequently, more information is becoming available on nutritional energetics and has been summarized by many researchers. ${ }^{5-8)}$

This series of studies on nutritional energetics in carp and rainbow trout aims to provide basic data necessary for standardization of feed quality evaluation for fish in captivity with special emphasis on their energy requirements. Measurements of gross energy (GE), DE, ME, heat increment (HI), and NE (maintenance, activity, and production) are required to investigate the energy metabolism in fish. This study set out to determine endogenous nitrogen excretion (ENE) which is essential for calculation of ME. It is technically difficult to determine
ME values of diets for fish because nitrogen losses across the gills and in urine must be measured. Many researchers ${ }^{9-12)}$ have attempted to solve these difficulties and have developed procedures for estimating ME values, although some involve considerable handling, and cause stress to the fish, resulting in increased nitrogen loss. $\left.{ }^{9}\right)$

In the present study, ENE through the gills and in the urine together with non-fecal energy losses were determined without giving any stress to fish by using the system developed by Ogino et al. ${ }^{13)}$ ENE is the amount of nitrogen excreted through the gills and in the urine when a fish is fed a non-protein diet. On the contrary, when a fish is fed a protein diet, nitrogen excreted includes that derived from dietary protein apart from the endogenous production. ENE is also reported to be influenced by fish size ${ }^{14)}$ and water temperature. ${ }^{13,14)}$ The effects of these additional factors on ENE were also examined in carp and rainbow trout.

\section{Materials and Methods}

\section{Non-fecal Nitrogen Collection System}

Nitrogen excretion through the gills and in the urine (non-fecal nitrogen) was determined by the system developed by Ogino et al. ${ }^{13)}$ which allows separate collection of metabolic fecal and endogenous nitrogens. Water from the fish tank is continuously siphoned through a trap column where feces are retained and precipitated by cupric hydroxide as a protein precipitator (in a bacteriafree environment), and thence to a large column (5.5x $60 \mathrm{~cm}$ ) containing a strongly basic cation exchange resin (Amberlite IR-120H) where cationic substances are retained. These substances are eluted from the column with

\footnotetext{
$\dagger$ Nutritional Energetics in Fish-I.
} 
$5 \%(\mathrm{w} / \mathrm{v}) \mathrm{HCl}$ at the end of the experiment. The method can also be used to measure the nitrogen balance in fish that are not stressed, but not for neutral and anionic substances like urea and taurine. Ogino et al. demonstrated that all non-fecal nitrogen is collected by the column, and that urea was not excreted by carp. This apparatus can also be employed for rainbow trout in which nitrogenous wastes are assumed to contain $85 \%$ ammonia and $15 \%$ urea. The details of sampling and analytical procedures involved in the system have been described in the paper of Ogino et al. ${ }^{13)}$

\section{Determination of Endogenous Nitrogen Excretion}

In Experiment I carp weighing about $14-247 \mathrm{~g}$ were divided into 6 groups of 2 to 15 fish each according to fish body weight, kept in $40 l$ tanks with aeration and fed a protein-free diet to satiation three times daily $(09: 30,11: 30$, $17: 30$ ) for 20 and 23 days at a water temperature of $27-28^{\circ} \mathrm{C}$. The rate of water supply to each tank was $400-500 \mathrm{~m} / / \mathrm{min}$. ENE was determined in each case one day after terminating the feeding experiment, namely the 21 st and 24 th day from 12:00 for $24 \mathrm{~h}$.

In Experiment II carp weighing about $7-289 \mathrm{~g}$ were starved for one day and anesthetized with benzocaine to determine body weight and divided into 4-6 lots of 2-20 fish each based on body weight. The protein-free diet was given to each group of fish three times daily, in total about $2 \%$ of body weight from $17: 30$ on the same day of body weight determination to $09: 30$ and 11:30 the next day and this feeding schedule was continued for 4 days. After feeding the final meal at 11:30 on the 4th day, the fish of each test group were transferred to the tanks of the system described above at 12:00 and kept for $24 \mathrm{~h}$ without feeding at a water temperature of 20 and $21^{\circ} \mathrm{C}$ to measure ENE. The fish body weight and total amount of diet accepted by fish were recorded for each treatment after $24 \mathrm{~h}$.

In Experiment III four groups of 10 carp, each having a mean initial weight of $25 \mathrm{~g}$, were fed the non-protein diet at a level of about $2 \%$ of body weight three times daily $(09: 30,11: 30,17: 30)$ for 17 days. ENE was determined on the 5 th, 8 th, 14 th, and 18 th day after feeding the non-protein diet by the same procedure as Expt. II.

In Experiment IV carp with an average body weight of about $25 \mathrm{~g}$ were fed the non-protein diet at levels of 1,2 , and $3 \%$ of body weight three times daily for 4 days at $21^{\circ} \mathrm{C}$ and nitrogen excretion was measured on the 5th day.

In the experiment with rainbow trout fish weighing about 8 to $157 \mathrm{~g}$ were divided based on their body weight into 4 lots for the experiment at $21^{\circ} \mathrm{C}, 3$ lots at $19^{\circ} \mathrm{C}$, and 8 lots at $14^{\circ} \mathrm{C}$ and fed for 4 days with the protein-free diet at a level of $2 \%$ of body weight, three times daily.

In these experiments effects of body weight, feeding levels and period, and water temperature on ENE were estimated.

\section{Recovery Test of Nitrogen Compounds by the System}

In the system described above a recovery test was conducted to examine whether or not nitrogen excreted through the gills and in the urine was quantitatively collected by the resin in the column in the same procedure as the practical determination without fish in the rearing tank. An aliquot of solution of a mixture containing ammonium chloride, creatine, and L-sodium aspartate $(524: 28: 8 \mathrm{mgN} /$ $100 \mathrm{ml}$ ) was added to the rearing tanks and water supplied
Table 1. Results of recovery test of nitrogen compounds by the column

\begin{tabular}{ccc}
\hline $\begin{array}{c}\text { Nitrogen* } \\
\text { loaded } \\
(\mathrm{mg})\end{array}$ & $\begin{array}{c}\text { Nitrogen } \\
\text { recovered } \\
(\mathrm{mg})\end{array}$ & $\begin{array}{c}\text { Recovery } \\
(\%)\end{array}$ \\
\hline 60.9 & 61.1 & 100.3 \\
137.5 & 139.3 & 101.3 \\
481.2 & 478.2 & 99.4 \\
687.5 & 681.3 & 99.1 \\
\hline
\end{tabular}

* A mixture of ammonium chloride, creatine, and L-sodium aspartate.

Table 2. Composition of non-protein diets for carp and rainbow trout $(\%)$

\begin{tabular}{lcc}
\hline Ingredients & Carp & $\begin{array}{c}\text { Rainbow } \\
\text { trout }\end{array}$ \\
\hline -Starch & 20 & 20 \\
Dextrin & 50 & 40 \\
Lipid*1 & 8 & 18 \\
Mineral mixture*2 & 5 & 5 \\
Vitamin mixture*3 & 2 & 2 \\
Cellulose & 15 & 15 \\
\hline
\end{tabular}

$* 1$ Soybean oil : pollock liver oil $=3: 2$, containing $1 \%$ DL- $\alpha$-tocopheryl acetate $* 2$ See ref. 18 .

*3 See ref. 19 .

to the tank was continuously siphoned through the trap and the resin column $(5.5 \times 60 \mathrm{~cm})$. The results are shown in Table 1. A mixture of three nitrogen compounds loaded at levels of $60-700 \mathrm{mg}$ was found to be almost completely collected by the resin column. This indicates that a fairly high number of fish can be kept in the rearing tank for measurement of nitrogen excretion across the gills and in the urine. The same result was also obtained by Ogino et $a l^{13)}$ except for urea of which very little was recovered. They also demonstrated that no nitrogen was detected in the water eluted from the column when several carp weighing $80-100 \mathrm{~g}$ were kept in the rearing tank. These results, together with the fact that nitrogenous waste compounds excreted through the gills or in the urine are mainly in the form of ammonia in freshwater teleost fish, ${ }^{15-17)}$ indicate the validity of the system for determining nitrogen excretion across the gills and in the urine.

\section{Composition of Experimental Diets}

The composition of the non-protein diet used for measurement of endogenous nitrogen in carp and rainbow trout is shown in Table 2 and was almost the same as that used by Ogino et al. ${ }^{20}$ ) The diet for rainbow trout had a high lipid content ${ }^{21)}$ and low carbohydrate content compared with that of carp.

The composition of the experimental diets used for measurement of non-fecal energy is shown in Table 3. Four kinds of diets containing different ratios of casein and gelatin as protein sources were prepared to examine the effect of protein quality on nitrogen excretion. The essential amino acid (EAA) index was greater than $99 \%$ for diets 1 and 2 , $91.1 \%$ for diet 3 , and $68.8 \%$ for diet 4 , thus diets 1 and 2 were normal, but diet 4 was an abnormal diet showing 
amino acid imbalance.

\section{Determination of Non-fecal Energy}

For the determination of non-fecal energy two carp or two rainbow trout were maintained in each tank. Three groups and double six groups or four groups and seven groups of carp weighing about $400-600 \mathrm{~g}$ were fed the experimental diets shown in Table 3 at about $1 \%$ of body

Table 3. Composition of experimental diets (\%)

\begin{tabular}{|c|c|c|c|c|}
\hline Ingredients & 1 & 2 & 3 & 4 \\
\hline Casein & 35 & 25 & 15 & 5 \\
\hline Gelatin & 0 & 10 & 20 & 30 \\
\hline Dextrin & 30 & 30 & 30 & 30 \\
\hline Feed oil & 8 & 8 & 8 & 8 \\
\hline Mineral mix. & 4 & 4 & 4 & 4 \\
\hline Vitamin mix. & 4 & 4 & 4 & 4 \\
\hline Ca lactate & 0 & 0.17 & 0.34 & 0.51 \\
\hline $\mathrm{NaH}_{2} \mathrm{PO}_{4}$ & 0.35 & 0.62 & 0.89 & 1.16 \\
\hline $\mathrm{CMC}$ & 5 & 5 & 5 & 5 \\
\hline$\alpha$-Cellulose & 13.65 & 13.21 & 12.77 & 12.33 \\
\hline \multicolumn{5}{|c|}{ Amino acid composition $(\mathrm{g} / 100 \mathrm{~g}$ diet $)$} \\
\hline Arg & 1.17 & 1.63 & 2.07 & 2.53 \\
\hline His & 0.91 & 0.75 & 0.58 & 0.42 \\
\hline Ile & 1.59 & 1.27 & 0.93 & 0.61 \\
\hline Leu & 2.96 & 2.40 & 1.82 & 1.25 \\
\hline Lys & 2.25 & 1.96 & 1.66 & 1.38 \\
\hline Met + Cys & 1.36 & 1.08 & 0.78 & 0.48 \\
\hline Phe + Tyr & 3.47 & 2.75 & 2.02 & 1.30 \\
\hline Thr & 1.35 & 1.14 & 0.93 & 0.72 \\
\hline Val & 1.95 & 1.63 & 1.30 & 0.97 \\
\hline $\operatorname{Trp}$ & 0.38 & 0.27 & 0.16 & 0.07 \\
\hline EAA index $(\%)$ & 99.30 & 99.74 & 91.10 & 68.82 \\
\hline \multirow[t]{2}{*}{ Crude protein $(\%)$} & 31.4 & 32.1 & 33.8 & 34.8 \\
\hline & -31.9 & -32.2 & -34.1 & -35.3 \\
\hline$----\cdots-1$ & $\ldots-\infty$ & ---- & ----- & ------ \\
\hline Gross energy & 4.63 & 4.46 & 4.43 & 4.33 \\
\hline$(\mathrm{kcal} / \mathrm{g})$ & -4.49 & -4.60 & -4.61 & -4.45 \\
\hline $\mathrm{Ca}(\%)$ & 0.46 & 0.46 & 0.46 & 0.46 \\
\hline $\mathrm{P} \quad(\%)$ & 0.72 & 0.72 & 0.72 & 0.72 \\
\hline
\end{tabular}

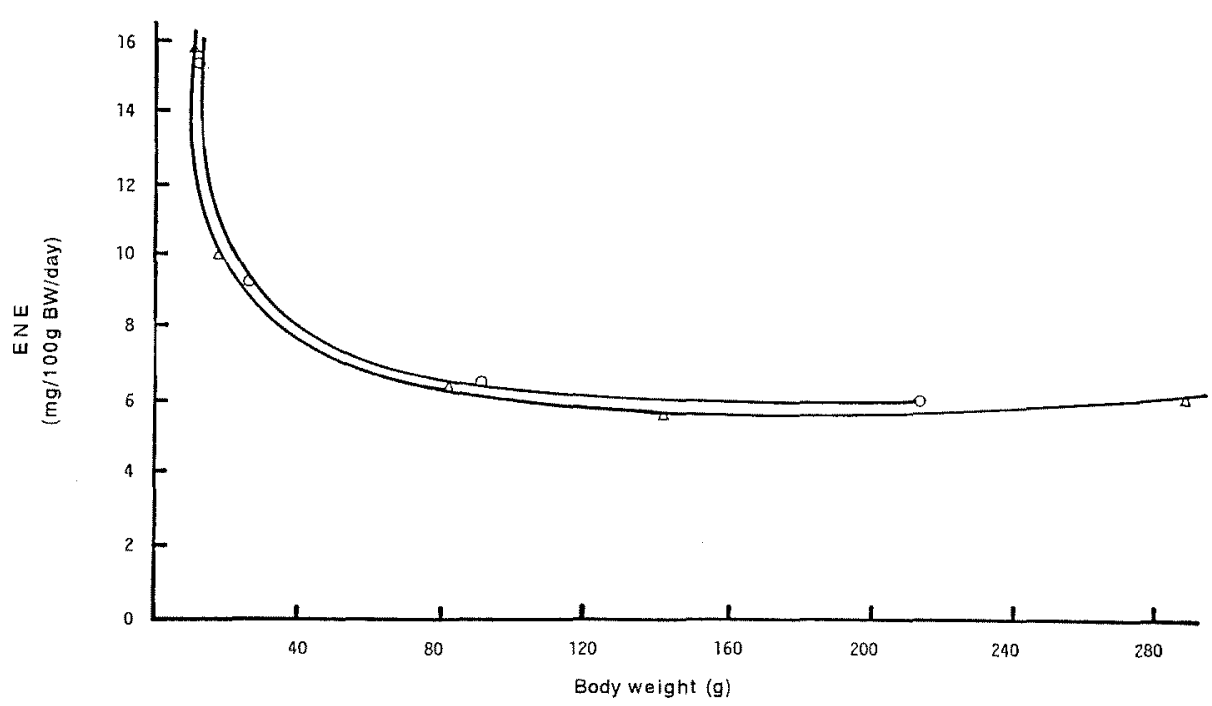

Fig. 1. Relationship between ENE and body weight from carp (Expt. II) $\mathrm{O}-\mathrm{O}, 21^{\circ} \mathrm{C} ; \triangle-\triangle, 20^{\circ} \mathrm{C}$. weight once daily (11:30) and or at about $0.75 \% 3$ times daily $(09: 30,11: 30,17: 30)$ at 20,23 , and $27^{\circ} \mathrm{C}$.

Eight groups and four groups or another eight groups of rainbow trout with body weight of about 200 to $600 \mathrm{~g}$ were also fed the experimental diets once or 3 times daily, at about $1 \%$ of body weight at both 7 and $16^{\circ} \mathrm{C}$, respectively. In both the experiments with carp and rainbow trout fish were fed the diets for 4 days and nitrogen excretion was measured on the 5th day. Procedures such as preliminary treatment of fish for nitrogen excretion were the same as those used for the determination of endogenous nitrogen. The values of $7.2,7.8$, and $8.6 \mathrm{mgN} / 100 \mathrm{~g}$ body weight/day at 20,23 , and $27^{\circ} \mathrm{C}$ respectively obtained by Ogino et al. ${ }^{13)}$ were used as those for endogenous nitrogen excretion in carp, and $8.5 \mathrm{mgN} / 100 \mathrm{~g}$ body weight/day for rainbow trout ${ }^{22)}$ at both 7 and $16^{\circ} \mathrm{C}$.

Non-fecal energy was calculated by multiplying the amount of non-fecal nitrogen by $5.94 \mathrm{kcal} / \mathrm{gNN},{ }^{23}$ the heats of combustion of ammonia, assuming that the nitrogen end product through the gills and in the urine is in the form of ammonia.

\section{Results and Discussion}

\section{Endogenous Nitrogen Excretion}

Carp: The amounts of ENE in carp fed the protein-free diet three times daily for 20 and 23 days at 27 and $28^{\circ} \mathrm{C}$ in

Table 4. Effect of body weight and feeding rates on ENE from carp (Expt. I)

\begin{tabular}{|c|c|c|c|c|c|c|}
\hline \multicolumn{2}{|c|}{ Body weight (g) } & \multirow{2}{*}{$\begin{array}{c}\text { No. } \\
\text { of } \\
\text { fish }\end{array}$} & \multirow{2}{*}{$\begin{array}{c}\text { Water } \\
\text { temp. } \\
\left.{ }^{\circ} \mathrm{C}\right)\end{array}$} & \multirow{2}{*}{$\begin{array}{c}\text { Days } \\
\text { of } \\
\text { feeding }\end{array}$} & \multirow{2}{*}{$\begin{array}{l}\text { Feeding } \\
\text { rate } \\
(\% / \text { day })\end{array}$} & \multirow{2}{*}{$\begin{array}{c}\text { ENE } \\
(\mathrm{mg} / 100 \mathrm{~g} \\
\mathrm{BW} / \text { day })\end{array}$} \\
\hline Range & Mean & & & & & \\
\hline $13.5-40.0$ & 27.3 & 15 & 27 & 20 & 2.0 & 6.9 \\
\hline $19.4 \quad 36.9$ & 25.9 & 12 & 27 & 20 & 2.0 & 7.5 \\
\hline $83.4-109.1$ & 84.7 & 5 & 28 & 23 & 1.3 & 5.4 \\
\hline $77.1-127.1$ & 100.0 & 4 & 28 & 23 & 1.3 & 5.8 \\
\hline $225.7-234.7$ & 230.2 & 2 & 28 & 23 & 1.3 & 2.4 \\
\hline $218.6-246.7$ & 232.7 & 2 & 28 & 23 & 1.3 & 3.9 \\
\hline
\end{tabular}


Expt. I are shown in Table 4. The values tended to decrease in proportion to fish body weight and were $2.4-5.8 \mathrm{mg} / 100 \mathrm{~g}$ body weight/day in fish of $85-233 \mathrm{~g}$ body weight fed the non-protein diet at $1.3 \%$ of body weight per day at $28^{\circ} \mathrm{C}$. The nitrogen excretion rates obtained by Ogino et al. ${ }^{13}$. were $7.6-9.2 \mathrm{mg}$ at $27^{\circ} \mathrm{C}$, and $6.0-8.0 \mathrm{mg} / 100 \mathrm{~g}$ body weight/day at $20^{\circ} \mathrm{C}$, when carp weighing $78-370 \mathrm{~g}$ were fed the protein-free diet at $2.2 \%$ of body weight per day for 3 days. A low level of feeding or a long-term feeding of the non-protein diet might result in lower levels of nitrogen excretion than those obtained by Ogino et al.

Thus in Expt. II the nitrogen excretion was determined under similar conditions to those of Ogino et al. in terms of feeding rate, fish size, and water temperatures. The results are indicated in Fig. 1 and Table 5. The rates of ENE were $5.6-6.5 \mathrm{mg} / 100 \mathrm{~g}$ body weight/day for fish of $81-286 \mathrm{~g}$ and close to those obtained by Ogino et al. They also determined for small carp weighing 2-10 g values of $11 \mathrm{mgN} / 100 \mathrm{~g}$ body weight/day at a water temperature ranging from $19-25^{\circ} \mathrm{C} .{ }^{22)}$ The values of 15.3-15.7 mg found in Expt. II with carp of about $10 \mathrm{~g}$ were slightly higher than those of Ogino et al. This difference may be explained by Fig. 1, which clearly indicates that ENE rate decreases with increase of fish body weight and with decrease of water temperature in fish of more than $20 \mathrm{~g}$. Savitz ${ }^{14)}$ also observed a reduced level of nitrogen excretion with decrease of water temperature in bluegill sunfish. Ogino et al. found no marked difference in the values between 20 and $27^{\circ} \mathrm{C}$ and used the average value of both temperatures to calculate net protein utilization. This average value may be valid for carp weighing more than $20 \mathrm{~g}$, but ENE rates in smaller carp

Table 5. Effect of body weight and water temperature on ENE from carp (Expt. II)

\begin{tabular}{rrrrrr}
\hline \multicolumn{2}{c}{ Body weight $(\mathrm{g})$} & $\begin{array}{c}\text { No. } \\
\text { of } \\
\text { Range }\end{array}$ & $\begin{array}{c}\text { Water } \\
\text { temp. } \\
(\mathrm{C})\end{array}$ & $\begin{array}{c}\text { Feeding } \\
\text { rate } \\
(\% / \text { day })\end{array}$ & $\begin{array}{c}\text { ENE } \\
(\mathrm{mg} / 100 \mathrm{~g} \\
\text { BW/day })\end{array}$ \\
\hline $9.7-15.8$ & 11.7 & 20 & 21 & 2.04 & 15.3 \\
$20.9-30.8$ & 25.3 & 10 & 21 & 2.02 & 9.3 \\
$80.0-96.9$ & 90.2 & 5 & 21 & 2.04 & 6.5 \\
$203.4-222.6$ & 213.0 & 2 & 21 & 2.03 & 6.0 \\
$7.3-12.3$ & 10.2 & 20 & 20 & 2.10 & 15.7 \\
$14.8-20.1$ & 17.6 & 15 & 20 & 2.11 & 10.0 \\
$26.0-39.8$ & 32.6 & 10 & 20 & 2.08 & 8.6 \\
$71.5-95.7$ & 81.3 & 5 & 20 & 2.06 & 6.4 \\
$137.0-146.2$ & 141.5 & 4 & 20 & 2.02 & 5.6 \\
$282.8-288.5$ & 285.7 & 2 & 20 & 2.06 & 6.0 \\
& & & & & Mean $=8.9$ \\
\hline
\end{tabular}

Table 6. Effect of feeding period on ENE from carp in Expt. III $\left(18-21^{\circ} \mathrm{C}\right)$

\begin{tabular}{ccccc}
\hline $\begin{array}{c}\text { Average } \\
\text { body } \\
\text { weight } \\
\text { (g) }\end{array}$ & $\begin{array}{r}\text { No. } \\
\text { of } \\
\text { fish }\end{array}$ & $\begin{array}{c}\text { Feeding } \\
\text { period } \\
\text { (days) }\end{array}$ & $\begin{array}{c}\text { Feeding } \\
\text { rate } \\
\text { (\%/day) }\end{array}$ & $\begin{array}{c}\text { ENE } \\
(\mathrm{mg} / 100 \mathrm{~g} \\
\text { BW/day) }\end{array}$ \\
\hline 25.3 & 10 & 4 & 2.02 & 9.3 \\
25.5 & 10 & 7 & 1.98 & 5.2 \\
25.4 & 10 & 13 & 2.01 & 6.8 \\
24.8 & 10 & 17 & 2.05 & 7.9 \\
& & & & Mean $=7.3$ \\
\hline
\end{tabular}

seemed to be affected by body weight rather than by water temperature. ENE should be measured for each size of smaller carp at different water temperatures.

The effect of feeding period with the non-protein diet on the ENE rates examined in Expt. III is shown in Table 6. The ENE rate was slightly higher in the fish fed the diet for 4 days than 7, 13, and 17 days, as observed in human beings fed a non-protein diet, ${ }^{24)}$ although the mean value during 17 days feeding was $7.3 \mathrm{mgN} / 100 \mathrm{~g}$ body weight/day.

The effect of feeding rate is also shown in Table 7 . The feeding rate of $1 \%$ or $3 \%$ of body weight/day resulted in higher nitrogen excretion than $2 \%$. This may suggest that the rate of ENE is influenced by energy intake and tissue protein is catabolized in case of a shortage of energy intake.

Rainbow trout: The ENE rates measured at 14, 19, and $21^{\circ} \mathrm{C}$ are shown in Table 8 . The mean value was $12.4 \mathrm{mg}$ at $21^{\circ} \mathrm{C}, 10.9 \mathrm{mg}$ at $19^{\circ} \mathrm{C}$, and $6.6 \mathrm{mgN} / 100 \mathrm{~g}$ body weight/ day at $14^{\circ} \mathrm{C}$. Thus the ENE rate was affected by water temperature, increasing in proportion to water temperature. The total average of all measurements at different temperatures was $9.0 \mathrm{mgN} / 100 \mathrm{~g}$ body weight/day, which is comparable to that obtained by Ogino et $a l^{22)}$ of

Table 7. Effect of feeding rate on ENE from carp in Expt. IV $\left(21^{\circ} \mathrm{C}\right)$

\begin{tabular}{cccc}
\hline $\begin{array}{c}\text { Average } \\
\text { body } \\
\text { weight } \\
(\mathrm{g})\end{array}$ & $\begin{array}{c}\text { No. } \\
\text { of } \\
\text { fish }\end{array}$ & $\begin{array}{c}\text { Feeding } \\
\text { rate } \\
(\% / \text { day })\end{array}$ & $\begin{array}{c}\text { ENE } \\
(\mathrm{mg} / 100 \mathrm{~g} \\
\text { BW/day) }\end{array}$ \\
\hline 23.9 & 10 & 1.05 & 13.1 \\
25.3 & 10 & 2.02 & 9.3 \\
26.5 & 10 & 3.05 & 13.0 \\
\hline
\end{tabular}

Table 8. Effect of body weight and water temperature on ENE from rainbow trout fed on non-protein diets for four days

\begin{tabular}{|c|c|c|c|c|c|}
\hline \multicolumn{2}{|c|}{ Body weight (g) } & \multirow{2}{*}{$\begin{array}{l}\text { No. } \\
\text { of } \\
\text { fish }\end{array}$} & \multirow{2}{*}{$\begin{array}{c}\text { Water } \\
\text { temp. } \\
\left({ }^{\circ} \mathrm{C}\right)\end{array}$} & \multirow{2}{*}{$\begin{array}{l}\text { Feeding } \\
\text { rate } \\
(\% / \text { day })\end{array}$} & \multirow{2}{*}{$\begin{array}{c}\text { ENE } \\
(\mathrm{mg} / 100 \mathrm{~g} \\
\mathrm{BW} / \text { day })\end{array}$} \\
\hline Range & Mean & & & & \\
\hline $97.9-118.6$ & 108.3 & 2 & 21 & 2.01 & 12.1 \\
\hline $117.7-129.1$ & 123.4 & 2 & 21 & 2.02 & 12.7 \\
\hline $130.3-150.1$ & 140.2 & 2 & 21 & 1.98 & 13.2 \\
\hline \multirow[t]{2}{*}{$135.4-157.2$} & 146.3 & 2 & 21 & 2.01 & 11.7 \\
\hline & & & & \multicolumn{2}{|c|}{ Mean $=12.4$} \\
\hline $87.1-106.1$ & 96.6 & 2 & 19 & 1.95 & 11.0 \\
\hline $119.3-128.2$ & 123.8 & 2 & 19 & 1.92 & 10.7 \\
\hline \multirow[t]{2}{*}{$139.5-144.9$} & 142.2 & 2 & 19 & 1.94 & 10.9 \\
\hline & & & & \multicolumn{2}{|c|}{ Mean $=10.9$} \\
\hline $7.8-15.8$ & 12.8 & 15 & 14 & 1.95 & 6.1 \\
\hline $9.1-17.4$ & 13.4 & 15 & 14 & 1.96 & 7.3 \\
\hline $12.5-18.5$ & 16.0 & 10 & 14 & 1.91 & 7.0 \\
\hline $24.9-38.9$ & 30.1 & 8 & 14 & 1.96 & 5.4 \\
\hline $27.0-34.7$ & 31.3 & 8 & 14 & 1.97 & 5.8 \\
\hline $36.8-42.9$ & 38.9 & 6 & 14 & 2.04 & 7.4 \\
\hline $33.0-43.2$ & 40.8 & 6 & 14 & 2.04 & 7.0 \\
\hline \multirow[t]{3}{*}{$67.7-77.5$} & 73.3 & 4 & 14 & 2.01 & 6.6 \\
\hline & & & & \multicolumn{2}{|c|}{ Mean $=6.6$} \\
\hline & & & & al avera & $=9.0$ \\
\hline
\end{tabular}


Table 9. Effect of water temperature and dietary quality on non-fecal energy losses in carp

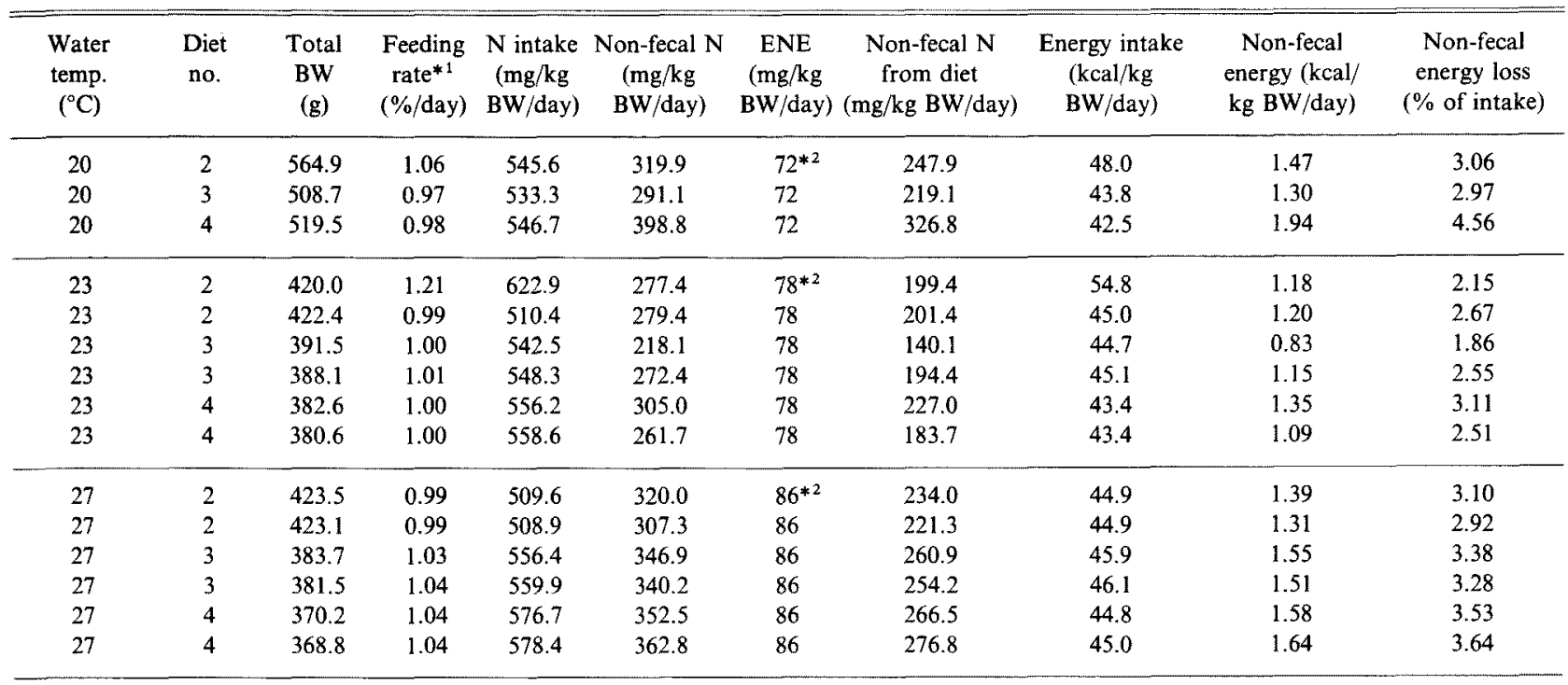

*1 Diets were given once a day.

*2 ENE rates were calculated as 72,78 , and $86 \mathrm{mg} / \mathrm{kg} \mathrm{BW} /$ day at 20,23 , and $27^{\circ} \mathrm{C}$, respectively.

Table 10. Effect of water temperature and dietary quality on non-fecal energy losses in rainbow trout

\begin{tabular}{|c|c|c|c|c|c|c|c|c|c|c|}
\hline $\begin{array}{l}\text { Water } \\
\text { temp. } \\
\left({ }^{\circ} \mathrm{C}\right)\end{array}$ & $\begin{array}{c}\text { Diet } \\
\text { no. }\end{array}$ & $\begin{array}{c}\text { Total } \\
\text { BW } \\
(\mathrm{g})\end{array}$ & $\begin{array}{l}\text { Feeding } \\
\text { rate }^{* 1} \\
(\% / \text { day })\end{array}$ & $\begin{array}{c}\mathrm{N} \text { intake } \\
(\mathrm{mg} / \mathrm{kg} \\
\mathrm{BW} / \text { day })\end{array}$ & $\begin{array}{c}\text { Non-fecal N } \\
(\mathrm{mg} / \mathrm{kg} \\
\mathrm{BW} / \text { day })\end{array}$ & $\begin{array}{c}\text { ENE } \\
(\mathrm{mg} / \mathrm{kg} \\
\mathrm{BW} / \text { day })\end{array}$ & $\begin{array}{c}\text { Non-fecal } \mathrm{N} \\
\text { from diet } \\
\text { (mg/kg BW/day) }\end{array}$ & $\begin{array}{c}\text { Energy intake } \\
(\mathrm{kcal} / \mathrm{kg} \\
\mathrm{BW} / \text { day })\end{array}$ & $\begin{array}{c}\text { Non-fecal } \\
\text { energy (kcal/ } \\
\text { kg BW/day) }\end{array}$ & $\begin{array}{c}\text { Non-fecal } \\
\text { energy loss } \\
\text { (\% of intake) }\end{array}$ \\
\hline 7 & 2 & 377.4 & 0.93 & 477.5 & 200.8 & $85 * 2$ & 115.8 & 42.1 & 0.69 & 1.64 \\
\hline 7 & 2 & 396.4 & 0.96 & 492.4 & 260.6 & 85 & 175.6 & 43.4 & 1.04 & 2.40 \\
\hline 7 & 2 & 399.4 & 0.99 & 510.5 & 246.6 & 85 & 161.6 & 44.8 & 0.96 & 2.14 \\
\hline 7 & 3 & 326.1 & 0.90 & 488.2 & 236.4 & 85 & 151.4 & 40.2 & 0.90 & 2.24 \\
\hline 7 & 3 & 341.9 & 0.99 & 533.8 & 306.8 & 85 & 221.8 & 43.9 & 1.32 & 3.01 \\
\hline 7 & 4 & 201.5 & 0.95 & 527.0 & 326.6 & 85 & 241.6 & 41.2 & 1.44 & 3.50 \\
\hline 7 & 4 & 199.7 & 1.01 & 562.8 & 381.1 & 85 & 296.1 & 43.6 & 1.76 & 4.04 \\
\hline 16 & 2 & 320.3 & 0.99 & 506.4 & 336.2 & $85^{* 2}$ & 251.2 & 44.6 & 1.49 & 3.34 \\
\hline 16 & 3 & 308.5 & 1.08 & 541.0 & 357.9 & 85 & 272.9 & 48.0 & 1.62 & 3.38 \\
\hline 16 & 4 & 448.0 & 0.96 & 583.9 & 444.4 & 85 & 359.4 & 45.3 & 2.13 & 4.70 \\
\hline 16 & 4 & 314.9 & 0.98 & 544.9 & 398.2 & 85 & 313.2 & 42.2 & 1.86 & 4.41 \\
\hline
\end{tabular}

*1 Diets were given once a day.

*2 ENE rate was calculated as $85 \mathrm{mg} / \mathrm{kg} \mathrm{BW} /$ day for both 7 and $16^{\circ} \mathrm{C}$.

$8.5 \mathrm{mgN} / 100 \mathrm{~g}$ body weight/day in fish weighing 2-10g at $12-19^{\circ} \mathrm{C}$. In contrast with carp no marked difference was observed in the ENE rates with regard to fish body weight.

Effect of Water Temperature on Non-fecal Energy Losses

The effect of water temperature on non-fecal losses, namely nitrogen excretion across the gills or in the urine in both carp and rainbow trout fed diets of different protein quality is shown in Tables 9 and 10.

Carp: The proportion of non-fecal energy to gross energy of the diets determined at 20,23 , and $27^{\circ} \mathrm{C}$ was $3.1 \%$, $2.2-2.7 \%$, and $2.9-3.1 \%$ for diet $2,3.0 \%, 1.9-2.6 \%$, and $3.3-3.4 \%$ for diet 3 , and $4.6 \%, 2.5-3.1 \%$, and $3.5-3.6 \%$ for diet 4 , respectively at each temperature. The non-fecal energy losses were slightly higher in the fish fed the diet low in protein quality, but were not so affected by water temperature ranging from $20-27^{\circ} \mathrm{C}$.

Rainbow trout: The non-fecal energy losses were determined at 7 and $16^{\circ} \mathrm{C}$. The proportion of energy losses at both temperatures was $1.6-2.4 \%$ and $3.3 \%$ for diet 2 , $2.2-3.0 \%$ and $3.4 \%$ for diet 3 , and $3.5-4.0 \%$ and $4.4-4.7 \%$ for diet 4 . The non-fecal energy losses tended to increase with increase of water temperature and with decrease of protein quality. Hunn ${ }^{25)}$ reported that the excretion of urine increased from 52.8 to $100.8 \mathrm{ml} / \mathrm{kg}$ body weight/day with increase of water temperature from 10 to $20^{\circ} \mathrm{C}$ in rainbow trout. Kaushik ${ }^{11)}$ also found that the total nitrogen (ammonia + urea) excretion rate was $16 \mathrm{mg} / \mathrm{kg}$ body weight $/ 100 \mathrm{mgN}$ consumed/day at a water temperature of $10^{\circ} \mathrm{C}$ and increased to $29 \mathrm{mgN}$ on the first day after positive thermal shock of $18^{\circ} \mathrm{C}$. The rate stabilized by the 7 th day at about $20 \mathrm{mgN} / \mathrm{kg}$ body weight $/ 100 \mathrm{mgN}$ consumed/day, although the proportion of energy lost through non-fecal 
Table 11. Effect of water temperature and dietary quality on non-fecal energy losses in rainbow trout using the extrapolated ENE rate

\begin{tabular}{|c|c|c|c|c|c|c|c|c|c|}
\hline $\begin{array}{l}\text { Water } \\
\text { temp. } \\
\left({ }^{\circ} \mathrm{C}\right)\end{array}$ & $\begin{array}{c}\text { Diet } \\
\text { no. }\end{array}$ & $\begin{array}{c}\mathrm{N} \text { intake } \\
(\mathrm{mg} / \mathrm{kg} \\
\mathrm{BW} / \text { day })\end{array}$ & $\begin{array}{c}\text { Non-fecal N } \\
(\mathrm{mg} / \mathrm{kg} \\
\mathrm{BW} / \text { day })\end{array}$ & $\begin{array}{l}\text { Non-fecal } \mathrm{N}(\mathrm{mg} / \mathrm{kg} \\
\text { BW/100 } \mathrm{mg} \mathrm{N} \\
\text { consumed/day) }\end{array}$ & $\begin{array}{c}\mathrm{ENE} \\
(\mathrm{mg} / \mathrm{kg} \\
\mathrm{BW} / \text { day })\end{array}$ & $\begin{array}{c}\text { Non-fecal N } \\
\text { from diet } \\
\text { (mg/kg BW/day) }\end{array}$ & $\begin{array}{c}\text { Energy intake } \\
(\mathrm{kcal} / \mathrm{kg} \\
\mathrm{BW} / \text { day })\end{array}$ & $\begin{array}{c}\text { Non-fecal } \\
\text { energy }(\mathrm{kcal} / \mathrm{kg} \\
\text { BW/day) }\end{array}$ & $\begin{array}{c}\text { Non-fecal } \\
\text { energy loss } \\
\text { (\% of intake) }\end{array}$ \\
\hline 7 & 2 & 477.5 & 200.8 & 42.1 & $40^{* 1}$ & 160.8 & 42.1 & 0.96 & 2.28 \\
\hline 7 & 2 & 492.4 & 260.6 & $\$ 2.9$ & 40 & 220.6 & 43.4 & 1.31 & 3.02 \\
\hline 7 & 2 & 510.5 & 246.6 & 48.3 & 40 & 206.6 & 44,8 & 1.23 & 2.75 \\
\hline 7 & 3 & 488.2 & 236.4 & 48.4 & 40 & 196.4 & 40.2 & 1.17 & 2.91 \\
\hline 7 & 3 & 515.4 & 268.3 & $\$ 2.1$ & 40 & 228.3 & 42.3 & 1.36 & 3.22 \\
\hline 7 & 3 & 533.8 & 306.8 & 57.5 & 40 & 266.8 & 43.9 & 1.58 & 3.60 \\
\hline 7 & 4 & 527.0 & 326.6 & 62.0 & 40 & 286.6 & 41.2 & 1.70 & 4.13 \\
\hline 7 & 4 & 562.8 & 381.1 & 67.7 & 40 & 341.1 & 43.6 & 2.03 & 4.66 \\
\hline 16 & 2 & 506.4 & 336.2 & 66.4 & $85^{* 2}$ & 251.2 & 44.6 & 1.49 & 3.34 \\
\hline 16 & 3 & 541.0 & 357.9 & 66.2 & 85 & 272.9 & 48.0 & 1.62 & 3.38 \\
\hline 16 & 4 & 583.9 & 444.4 & 76.1 & 85 & 359.4 & 45.3 & 2.13 & 4.70 \\
\hline
\end{tabular}

*1 ENE rate was recalculated as $40 \mathrm{mg} / \mathrm{kg} \mathrm{BW} /$ day obtained by extrapolation at $7^{\circ} \mathrm{C}$.

*2 ENE rate was calculated as $85 \mathrm{mg} / \mathrm{kg} \mathrm{BW} /$ day at $16^{\circ} \mathrm{C}$.

Table 12. Effect of feeding frequency on non-fecal energy losses in carp $\left(20^{\circ} \mathrm{C}\right)$ and rainbow trout $\left(7^{\circ} \mathrm{C}\right)$

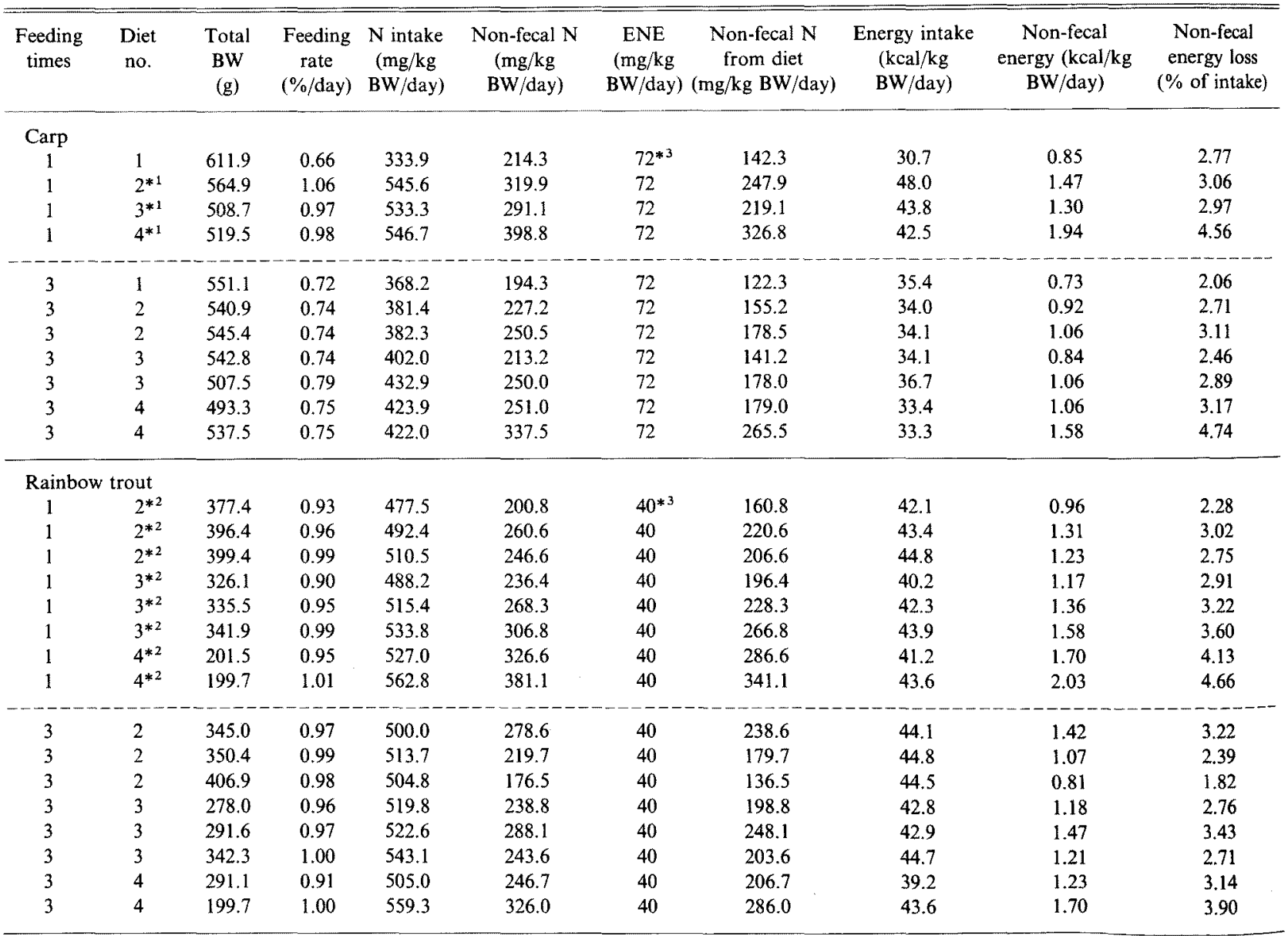

* 1 Data were cited from those determined at $20^{\circ} \mathrm{C}$ shown in Table 9.

*2 Data were cited from those determined at $7^{\circ} \mathrm{C}$ shown in Table 11

*3 ENE rates were calculated as 72 and $40 \mathrm{mg} / \mathrm{kg} \mathrm{BW} /$ day in carp and rainbow trout

matter was not affected by temperature, remaining at about $3 \%$. The proportion, however, increased with temperature for each diet in our experiment in which the total nitrogen and energy intake were lower than in his experiment. The total non-fecal nitrogen excretion rates were calculated based on $\mathrm{mgN} / \mathrm{kg}$ body weight $/ 100 \mathrm{mgN}$ 


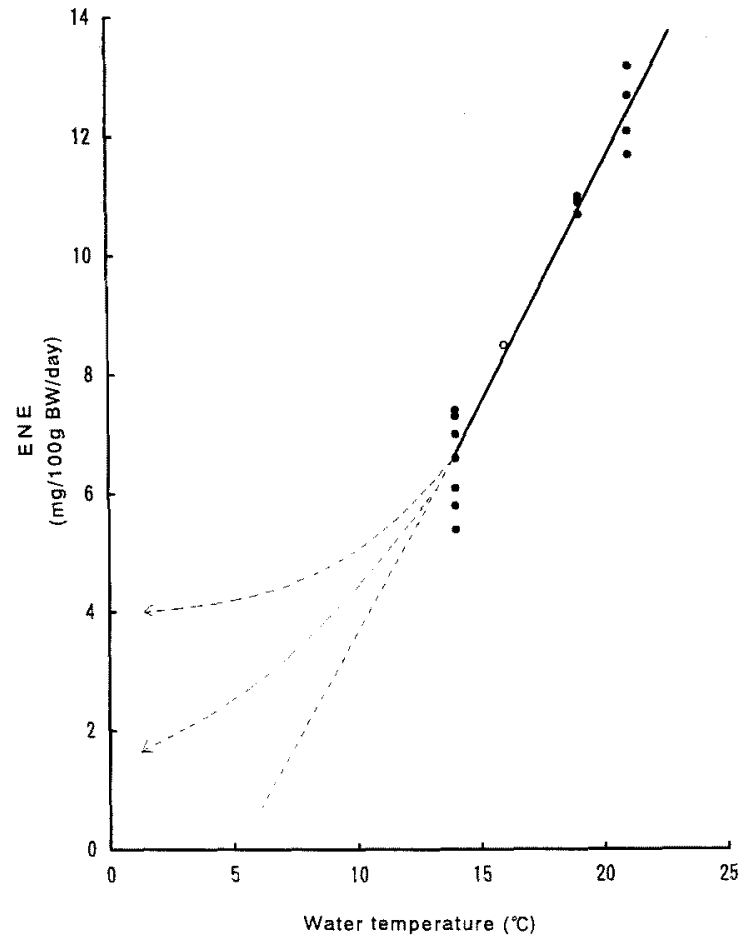

Fig. 2. Relationship between ENE and water temperature in rainbow trout.

- - : Lines on the basis of estimated ENE values.

consumed/day and are shown in Table 11. A comparison of the rates between 7 and $16^{\circ} \mathrm{C}$ clearly indicates that the rates increase with temperature. This might be due to the fact that for the calculation of non-fecal nitrogen excretion derived from the diets, the value of $8.5 \mathrm{mgN} / 100 \mathrm{~g}$ body weight/day was used as the ENE rate for both 7 and $16^{\circ} \mathrm{C}$. However, the value was greatly affected by water temperature as shown in Fig. 2; the average value of $12.4 \mathrm{mgN}$ at $21^{\circ} \mathrm{C}$ was reduced to $10.9 \mathrm{mg}$ at $19^{\circ} \mathrm{C}$ and to $6.6 \mathrm{mgN}$ at $14^{\circ} \mathrm{C}$, giving a value of about $8.5 \mathrm{mgN}$ at $16^{\circ} \mathrm{C}$ due to a linear relationship between the rate and temperature, but the value seems to be very high for the water temperature of $7^{\circ} \mathrm{C}$. When the value of $3-4 \mathrm{mgN} / 100 \mathrm{~g}$ body weight/day obtained by extrapolation to $7^{\circ} \mathrm{C}$ in the curves of Fig. 2 is used as the ENE rate at $7^{\circ} \mathrm{C}$, the proportion of non-fecal energy losses becomes almost the same for the two temperatures, as shown in Table 11.

\section{Effect of Feeding Frequency on Non-fecal Energy Losses}

The effect of feeding frequency on nitrogen excretion was compared for feeding once and three times daily as shown in Table 12. There were no marked differences in the non-fecal losses among the fish fed the same diet once or three times daily at levels less than $1 \%$ of body weight.

\section{Conclusion}

The system developed by Ogino et al. ${ }^{13)}$ was confirmed to be effective to determine endogenous nitrogen in both carp and rainbow trout, although urea nitrogen is not collected. Endogenous nitrogen excretion $(\mathrm{mgN} / 100 \mathrm{~g}$ body weight/day) from carp was higher in fish weighing ten than
$20 \mathrm{~g}$ and decreases with temperature in fish weighing more than $20 \mathrm{~g}$. The values are $5.6-6.5 \mathrm{mg}$ in fish of $81-286 \mathrm{~g}$ and $15.3-15.7 \mathrm{mg}$ in fish of about $10 \mathrm{~g}$ at $20-21^{\circ} \mathrm{C}$. The ENE rates in rainbow trout were proportional to water temperature, ranging from $6.6 \mathrm{mg}$ at $14^{\circ} \mathrm{C}$ to $12.4 \mathrm{mg}$ at $21^{\circ} \mathrm{C}$. The proportion of energy lost through non-fecal wastes seems to be not so influenced by temperature, depending upon the ENE values used for calculation at each temperature. The dietary protein quality affects non-fecal nitrogen excretion in both species, and nonfecal losses increase in fish fed the amino acid imbalanced diet.

\section{References}

1) NRC (National Research Council): Nutrient Requirements of Swine, National Academy Press, Washington D.C., 1988, pp. 1-93.

2) NRC (National Research Council): Nutrient Requirements of Dairy Cattle, National Academy of Sciences, Washington D.C., 1978, pp. $1-76$.

3) Japanese Feeding Standard for Swine (ed. by Agriculture, Forestry and Fisheries Research Council Secretariat Ministry of Agriculture, Forestry and Fisheries), Central Association of Livestock Industry, Tokyo, 1987, pp. 1-75 (in Japanese).

4) K. Kouga and T. Suzuki: Energugyi, Doubutu no eiyouyoukyuu to haigoushiryou, in "Haigoushiryou Kouza" (ed. by Haigoushiryou Kouza Hensan Iinkai), The first volume, 2nd ed., Chikusan Syuppan-Sha, Tokyo, 1981, pp. 34-66 (in Japanese).

5) C. Y. Cho, S. J. Slinger, and H. S. Bayley: Bioenergetics of salmonid fishes: Energy intake, expenditure and productivity. Comp. Biochem. Physiol, 73B, 25-41 (1982).

6) J. R. Brett and T. D. D. Groves: Physiological energetics, in "Fish Physiology" (ed. by W. S. Hoar, D. J. Randall, and J. R. Brett), Vol. 8, Academic Press, New York, 1979, pp. 279-352.

7) B. R. Braaten: Bioenergetics-A review on methodology. Proc. World Symp. on Finfish Nutrition and Fishfeed Technology. Hamburg, June 20-23, Vol. II, 1979, pp. 461-504.

8) J. M. Elliott: The effects of temperature and ration size on the growth and energetics of salmonids in captivity. Comp. Biochem. Physiol., 73B, 81-91 (1982).

9) R. R. Smith: A method for measuring digestibility and metabolizable energy of fish feeds. Prog. Fish-Cult., 33, 132-134 (1971).

10) J. M. Elliott: Energy losses in the waste products of brown trout (Salmo trutta). J. Anim. Ecol, 45, 561-580 (1976).

11) S. J. Kaushik: Influence of a rise in temperature on the nitrogen excretion of rainbow trout (Salmo gairdneri). Proc. World Symp. on Aquaculture in Heated Effluents and Recirculation Systems. Stavanger, May 28-30, Vol. I, 1981, pp. 78-87.

12) J. Rychly: Nitrogen balance in trout II. Nitrogen excretion and retention after feeding diets with varying protein and carbohydrate levels. Aquaculture, 20, 343-350 (1980).

13) C. Ogino, J. Kakino, and M. S. Chen: Protein nutrition in fish-II. Determination of metabolic fecal nitrogen and endogenous nitrogen excretions of carp. Nippon Suisan Gakkaishi, 39, 519-523 (1973).

14) J. Savitz: Effects of temperature and body weight on endogenous nitrogen excretion in the bluegill sunfish (Lepomis macrochirus). $J$. Fish. Res Bd. Canada, 26, 1813-1821 (1969).

15) H. Ozaki: Nyou no kagakutekiseibun, in "Gyorui Seirigaku Kouza" Vol. 6, Midori Shobou, Tokyo, 1977, pp. 147-236 (in Japanese).

16) A. Furukawa and $Y$. Ogasawara: Studies on nutrition of fish-V. The excretion of $\mathrm{NH}_{3}-\mathrm{N}$ and urea-N by carp and goldfish. Nippon Suisan Gakkaishi, 21, 119-122 (1955).

17) S. Shimeno, M. Takeda, and H. Sasaki: Response of nitrogen excretion to change of dietary composition in carp. Nippon Suisan Gakkaishi, 47. 191-195 (1981).

18) C. Ogino, L. Takeuchi, H. Takeda, and T. Watanabe: Availability of dietary phosphorus in carp and rainbow trout. Nippon Suisan Gakkaishi, 45, 1527-1532 (1979).

19) C. Ogino and G. Y. Yang: Requirement of rainbow trout for dietary 
zinc. Nippon Suisan Gakkaishi, 44, 1015-1018 (1978).

20) C. Ogino, H. Kawasaki, and H. Nanri: Method for the determination of nitrogen retained in the fish body by the carcass analysis. Nippon Suisan Gakkaishi, 46, 105-108 (1980).

21) C. Ogino, J. Y. Chion, and T. Takeuchi: Protein nutrition in fish-VI. Effects of dietary energy sources on the utilization of proteins by rainbow trout and carp. Nippon Suisan Gakkaishi, 42, 213-218 (1976).

22) C. Ogino: Tanpakushitu, Gyorui no eiyouso ni taisuru youkyuu, in
"Gyorui no Eiyou to Shiryou" (ed. by C. Ogino), 1st ed., Koseisha-Koseikaku, Tokyo, 1980, pp. 111-139 (in Japanese).

23) J. M. Elliott and W. Davison: Energy equivalents of oxygen consumption in animal energetics. Oecologia., 19, 195-201 (1975).

24) G. Inoue: Hito no tanpakushituhituyouryou, in "Tanpakushitu Aminosan no Eiyougaku" (ed. by N. Shimazono and I. Nakagawa), 1st ed., Asakura Shoten, Tokyo, 1964, pp. 289-312 (in Japanese).

25) J. B. Hunn: Urine flow rate in freshwater salmonids: A review. Prog. Fish-Cult, 44, 119-125 (1982). 